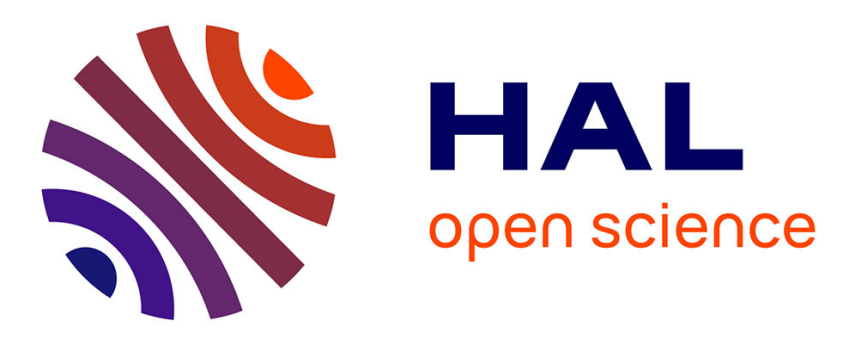

\title{
Photocatalytic degradation of an azo-dye on TiO2/ activated carbon composite material
}

\author{
Caroline Andriantsiferana, Elham Farouk Mohamed, Henri Delmas
}

\section{To cite this version:}

Caroline Andriantsiferana, Elham Farouk Mohamed, Henri Delmas. Photocatalytic degradation of an azo-dye on TiO2/ activated carbon composite material. Environmental Technology, 2014, vol. 35 (n ${ }^{\circ}$ 3), pp. 355-363. 10.1080/09593330.2013.828094 . hal-01153077

\section{HAL Id: hal-01153077 \\ https://hal.science/hal-01153077}

Submitted on 19 May 2015

HAL is a multi-disciplinary open access archive for the deposit and dissemination of scientific research documents, whether they are published or not. The documents may come from teaching and research institutions in France or abroad, or from public or private research centers.
L'archive ouverte pluridisciplinaire HAL, est destinée au dépôt et à la diffusion de documents scientifiques de niveau recherche, publiés ou non, émanant des établissements d'enseignement et de recherche français ou étrangers, des laboratoires publics ou privés. 


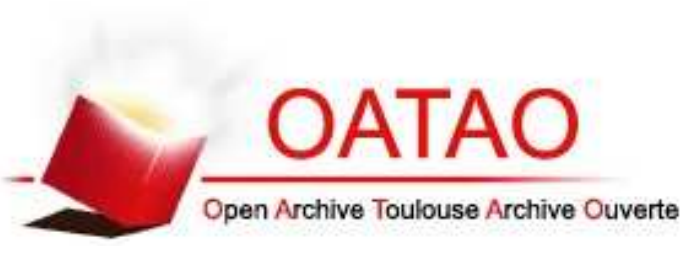

\section{Open Archive TOULOUSE Archive Ouverte (OATAO)}

OATAO is an open access repository that collects the work of Toulouse researchers and makes it freely available over the web where possible.

This is an author-deposited version published in : http://oatao.univ-toulouse.fr/ Eprints ID : 9721

Tolink to this article : DOI: $10.1080 / 09593330.2013 .828094$

URL : http://dx.doi.org/10.1080/09593330.2013.828094

To cite this version :

Andriantsiferana, Caroline and Mohamed, Elham Farouk and Delmas, Henri Photocatalytic degradation of an azo-dye on TiO2/ activated carbon composite material. (2013) Environmental Technology . pp. 1-9. ISSN 0959-3330 


\title{
Photocatalytic degradation of an azo-dye on $\mathrm{TiO}_{2}$ /activated carbon composite material
}

\author{
C. Andriantsiferana ${ }^{a *}$, E.F. Mohamed ${ }^{\mathrm{b}}$ and H. Delmas ${ }^{\mathrm{a}}$ \\ ${ }^{a}$ Laboratoire de Génie Chimique, UMR CNRS 5503, Université de Toulouse, INP, ENSIACET, 4, allée Emile MONSO-BP \\ 84234-31432 Toulouse Cedex 4, France; ${ }^{b}$ Department of Air Pollution, National Research Centre, El-Behoos \\ Street, Dokki, Giza, Egypt
}

\begin{abstract}
A sequential adsorption/photocatalytic regeneration process to remove tartrazine, an azo-dye in aqueous solution, has been investigated. The aim of this work was to compare the effectiveness of an adsorbent/photocatalyst composite $-\mathrm{TiO}_{2}$ deposited onto activated carbon (AC) - and a simple mixture of powders of $\mathrm{TiO}_{2}$ and $\mathrm{AC}$ in same proportion. The composite was an innovative material as the photocatalyst, $\mathrm{TiO}_{2}$, was deposited on the porous surface of a microporous-AC using metal-organic chemical vapour deposition in fluidized bed. The sequential process was composed of two-batch step cycles: every cycle alternated a step of adsorption and a step of photocatalytic oxidation under ultra-violet $(365 \mathrm{~nm})$, at $25^{\circ} \mathrm{C}$ and atmospheric pressure. Both steps, adsorption and photocatalytic oxidation, have been investigated during four cycles. For both materials, the cumulated amounts adsorbed during four cycles corresponded to nearly twice the maximum adsorption capacities $q_{\max }$ proving the photocatalytic oxidation to regenerate the adsorbent. Concerning photocatalytic oxidation, the degree of mineralization was higher with the $\mathrm{TiO}_{2} / \mathrm{AC}$ composite: for each cycle, the value of the total organic carbon removal was $25 \%$ higher than that obtained with the mixture powder. These better photocatalytic performances involved better regeneration than higher adsorbed amounts for cycles 2, 3 and 4. Better performances with this promising material $-\mathrm{TiO}_{2}$ deposited onto $\mathrm{AC}$ - compared with $\mathrm{TiO}_{2}$ powder could be explained by the vicinity of photocatalytic and AC adsorption sites.
\end{abstract}

Keywords: activated carbon; adsorption; azo-dye; photocatalysis; regeneration; $\mathrm{TiO}_{2}$

\section{Introduction}

Various manufactures (textile, food, paper, plastics, etc.) produce large amounts of wastewater containing dyestuffs with intensive colour and toxicity. Azo-dyes represent the largest class of organic dyes listed in the Colour Index (60-70\% of the total).[1] These effluents may be introduced into ecosystem inducing perturbations to aquatic life. In most countries, the researchers are looking for appropriate treatments in order to remove these pollutants. The heterogeneous photocatalytic process using $\mathrm{TiO}_{2}$ as a catalyst is one of the most promising advanced oxidation processes. This process is based on the generation of very reactive species such as hydroxyl radicals $\left({ }^{\circ} \mathrm{OH}\right)$ that can oxidize a broad range of organic pollutants quickly and nonselectively.[2-6] However, some drawbacks due to $\mathrm{TiO}_{2}$ fine powder were faced when carrying out photocatalytic processes [7]: (1) separation of $\mathrm{TiO}_{2}$ powder from water is difficult; (2) the suspended $\mathrm{TiO}_{2}$ powder tends to aggregate especially at high concentrations.[8] Therefore, to overpass these problems, much attention has been paid to the development of supported $\mathrm{TiO}_{2} \cdot[9,10]$

Several studies have been published on the effect of the characteristics of the supported $\mathrm{TiO}_{2}$ photocatalysts,[11] such as crystal structure,[12] crystal size,[13,14] $\mathrm{TiO}_{2}$ loading,[15] specific surface area,[14] thickness of film [16] and their reactivity to obtain efficient photocatalysts or to optimize the operation parameters of the photocatalyst preparation process. Obviously, only $\mathrm{TiO}_{2}$ on the external surface of the support can be excited by light and induces the photocatalytic reaction, so the concentration of $\mathrm{TiO}_{2}$ on the external surface of the support is a critical parameter for such supported photocatalyst.[13,16-18]

Various support materials and coating methods have been proposed for degradation of several organic compounds.[19] When using supports such as silica, alumina, zeolites or clays,[20] no improvement of photoefficiency was observed. Among these supports, activated carbon (AC) is very promising for two reasons: (1) AC is able to adsorb the pollutants and then release them onto the surface of $\mathrm{TiO}_{2}$. Consequently, a higher concentration of pollutants around the $\mathrm{TiO}_{2}$ than that in the bulk solution is created leading to an increase in the degradation rate of the pollutants [21-24] and (2) the intermediates produced during degradation can be also adsorbed by AC and then further oxidized. Herrmann et al. [25] claimed synergistic effects for AC-supported $\mathrm{TiO}_{2}$ systems, referring to remarkable effects in the kinetics of pollutant degradation, the pollutant being more rapidly photodegraded when adding AC. 
Many techniques have been developed for immobilizing $\mathrm{TiO}_{2}$ catalysts onto solid surface, for example, in the past decade, various methods, including sol-gel,[26,27] hydrothermal,[28] precipitation,[29] dip coating,[30] and hydrolysis [31] and impregnation.[32] Recently, metalorganic chemical vapour deposition (MOCVD), an extensively used surface-coating technology, has been applied to the preparation of photocatalyst.[13,31,33] MOCVD production of supported catalysts offers the following advantages $[34,35]$ : (1) the produced materials are mainly on the external surface of the support; (2) it has little effect on the porous structure of the support due to the use of gases as precursors; (3) most of the traditional steps in catalyst preparation, such as saturation, drying and reduction can be avoided; (4) $\mathrm{TiO}_{2}$ coating by MOCVD strongly adheres on the surface of $\mathrm{AC}$ and (5) the coating properties are easily controlled.

In this study, a sequential method of treatment was carried out involving adsorption and then photocatalytic oxidation. It was a preliminary investigation towards a new version of the AD-OX process [36,37] by replacing wet catalytic air oxidation by photocatalysis. The water treatment was not achieved by oxidation but by adsorption, the oxidative step being needed only for pollutant degradation and subsequent $\mathrm{AC}$ regeneration. To degrade tartrazine, the selected reference azo-dye, two implementations of photocatalysis were compared: (1) the composite material, $\mathrm{TiO}_{2}$, being deposited on the porous surface of a commercial AC by MOCVD in a fluidized bed and (2) a simple powder mixture with some $\mathrm{AC}$ and dispersed $\mathrm{TiO}_{2}$.

\section{Experimental and methods}

\subsection{Materials}

Tartrazine is an azo-dye $\left(\mathrm{C}_{16} \mathrm{H}_{9} \mathrm{~N}_{4} \mathrm{Na}_{3} \mathrm{O}_{9} \mathrm{~S}_{2}\right)$ often called Yellow 5 supplied by Sigma Aldrich (Analytical standard, purity $>99 \%$ ). The AC used was a commercial AC S23 (PICA) produced from coconut. The photocatalyst was the titanium dioxide Millennium PC 500. The size of the crystallites was ranged between 5 and $10 \mathrm{~nm}$, the crystals presented an anatase structure $(>99 \%)$ with a specific surface area $\mathrm{S}_{\mathrm{BET}}$ of about $320 \mathrm{~m}^{2} \mathrm{~g}^{-1}$.

\subsection{The $\mathrm{TiO}_{2} / A C$ composite material}

The AC particles have been coated with $\mathrm{TiO}_{2}$ using MOCVD in a fluidized bed under atmospheric pressure. Details concerning the experimental set-up can be found in the studies by Cadoret et al. [38] and Reuge et al.[39] The reaction implying a chemical precursor (Titanium Tetra Isopropoxide supplied by Sigma Aldrich) which is decomposed to form $\mathrm{TiO}_{2}$. The fluidizing gas (containing $\mathrm{N}_{2}$ and the vapour of the precursor of $\mathrm{TiO}_{2}$ ) was supplied at the bottom of the fluidized bed, the flow rate of the gas ensured that particles were well fluidized leading to a homogeneous treatment of the particles. The operating conditions were: growth temperature $440^{\circ} \mathrm{C}$; carrier gas flow velocity $11.55 \mathrm{~cm} \mathrm{~s}^{-1}\left(3.3 U_{\mathrm{mf}}\right)$; bubbler temperature: $70^{\circ} \mathrm{C}$; titanium tetra iso-propoxide mole fraction: $1.3 \times 10^{-3}$ and time: $12 \mathrm{~h}$.

\subsection{Analytical methods}

\subsubsection{Characterization of the adsorbents}

The textural characterization was deduced from nitrogen adsorption at $77 \mathrm{~K}$ using a Micrometrics ST-2000 automated apparatus. The specific surface area $S_{\mathrm{BET}}$ was calculated from Brunauer Emmet Teller (BET) plot in the relative pressure range $\left(p / p_{0}\right)$ from 0.01 to 0.20 .[40] Horvath and Kawazoe [41] and Barrett et al. [42] methods were employed to assess the micropore and mesopore volumes, respectively. The mean pore diameter was deduced from the total porous volume at $p / p_{0}=0.98$ and the BET surface area. The true density was measured by helium pycnometry (ACCUPYC 1330TC). In addition, the elemental composition is obtained by energy dispersive $\mathrm{X}$-ray analysis (INCA system, Oxford Instrument) in tandem with a scanning electron microscopy (LEO $435 \mathrm{VP}$ ). Moreover to bring out the presence of $\mathrm{TiO}_{2}$-anatase and $\mathrm{TiO}_{2}$-rutile, the composite material was characterized using X-ray diffraction (XRD). XRD patterns were recorded at room temperature with a SEIFERT XRD 3000 spectrometer. The identification of the peaks characteristic to $\mathrm{TiO}_{2}$-anatase and $\mathrm{TiO}_{2}$-rutile was made using standards in the Joint Committee on Powder Diffraction Standards database. The distribution of particles size for each material was measured with a Mastersizer 2000 granulometer supplied by Malvern. For the $\mathrm{TiO}_{2} / \mathrm{AC}$ composite, the amount of $\mathrm{TiO}_{2}$ was determined by ICP-AES (inductively coupled plasma atomic emission spectrometry). An external certificated laboratory, the Service Central d'Analyse (CNRS), made these analyses by using the ICP-AES model ICAP (ThermoFisher Scientific).

\subsubsection{Liquid analysis}

The concentration of tartrazine has been determined by high performance liquid chromatography (HPLC) with ultraviolet (UV) detection (UV 2000 detector, Thermo Finnigan). The separation is achieved using a $\mathrm{C} 18$ reverse phase column (ProntoSIL C18 AQ) with a mobile phase composed of ultrapure water acidified by $\mathrm{H}_{2} \mathrm{SO}_{4}(\mathrm{pH}=1.4)$ and methanol (isocratic method 60/40), fed at $0.5 \mathrm{~mL} \mathrm{~min}^{-1}$. The detector's wavelength was set to $317 \mathrm{~nm}$ and the temperature of the column was maintained at $30^{\circ} \mathrm{C}$. The UV-visible spectrum of the tartrazine and the calibration curve are represented in Figure 1.

The total organic carbon (TOC) was also measured at the end of each photocatalytic step. First, the inorganic carbon present in the solution was eliminated with concentrated phosphoric acid (84\%) and the solution was degassed 

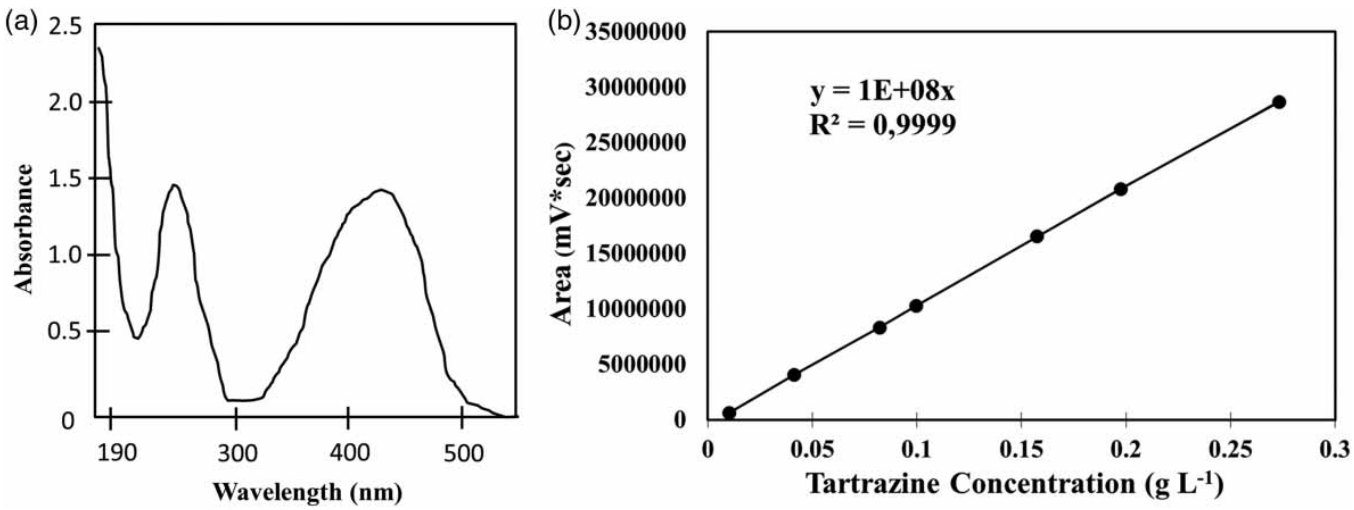

Figure 1. (a) UV-visible spectrum of tartrazine and (b) calibration curve for HPLC analysis.

by a current of nitrogen. The sample was then injected in a TOC-metre (TC Multi Analyser 2100 N/C), where the organic molecules were totally oxidized at $850^{\circ} \mathrm{C}$ in the presence of a platinum catalyst. The quantity of $\mathrm{CO}_{2}$ released by the reaction was then measured by infrared spectrometry.

\subsection{Experimental set-ups and procedures}

\subsubsection{Adsorption}

In brown flasks, $0.5 \mathrm{~g}$ of adsorbent was added to $100 \mathrm{~mL}$ of tartrazine solutions $\left(0.1-1.0 \mathrm{~g} \mathrm{~L}^{-1}\right.$ concentration range). Two different adsorbents were used: the $\mathrm{TiO}_{2} / \mathrm{AC}$ composite material and a mixture of $\mathrm{AC}$ and $\mathrm{TiO}_{2}$ in the same weight proportions. The suspensions were left under stirring in a thermo-regulated bath at $25^{\circ} \mathrm{C}$ for eight days to reach equilibrium. Then, the solutions were filtered on $0.25 \mu \mathrm{m}$ nylon filter membranes before analysis.[22] The amount of adsorbed tartrazine was deduced from initial and final HPLC measurements of concentrations in the liquid phase.

\subsubsection{Hybrid process}

Experiments were carried out in a $1 \mathrm{~L}$ cylindrical Pyrex reactor with air injection to provide oxygen (Figure 2).

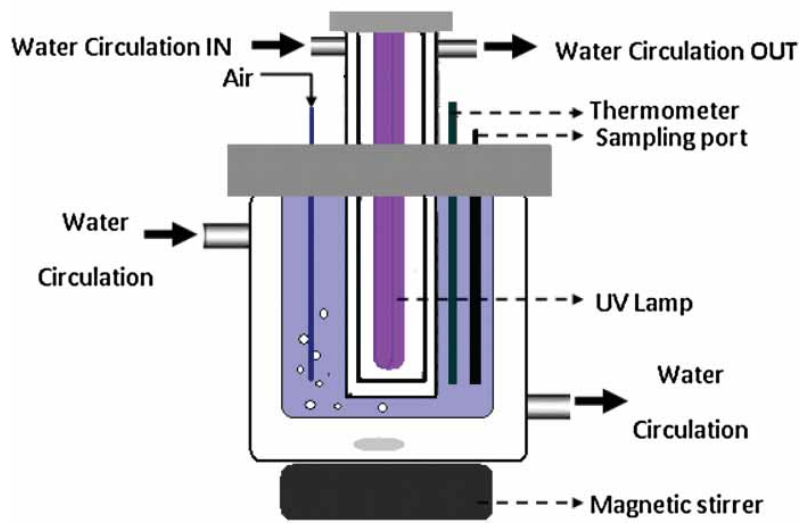

Figure 2. Experimental set-up.
On the central axis, a medium-pressure mercury lamp was placed in a jacketed thermo-regulated cylinder. The range of emission of the lamp (Philips PL-L 24W/10/4P) was $340-400 \mathrm{~nm}$ with a maximum at $365 \mathrm{~nm}$. The light intensity has been measured with a radiometer ultra-violet $\mathrm{A}$ Light Meter and is $47.5 \mathrm{~W} / \mathrm{m}^{2}$ (mean value of several measurements inside the reactor emptied and with water in the jacketed cylinder). The two jackets maintained the temperature at $25 \pm 1^{\circ} \mathrm{C}$. The external wall of the reactor jacket was covered with aluminium foil to reduce light losses. The solution was stirred with a magnetic stirrer. Tartrazine initial concentration was fixed at $0.40 \mathrm{~g} \mathrm{~L}^{-1}$ to start the adsorption/photo-oxidation run then it was regularly determined, thanks to the sampling performed as in adsorption experiments. As for adsorption alone the same two materials - $\mathrm{TiO}_{2} / \mathrm{AC}$ composite material $\left(7.9 \% \mathrm{TiO}_{2}\right)$ and a mixture of AC S23 (92.1\%) and $\mathrm{TiO}_{2}(7.9 \%)$ powders - at same concentration $\left(5 \mathrm{~g} \mathrm{~L}^{-1}\right)$ have been used as adsorbent and photocatalyst for comparison.

During the sequential process, two successive steps were achieved: adsorption and then photo-oxidation corresponding to one cycle. The adsorption step was carried out in the dark during several days (between five and seven days). Then, the oxidation step was conducted during three days under UV irradiation. During each step, the samples were taken at regular time intervals and analysed by HPLC and by a TOC-metre. After the oxidation step, the reactor was emptied of the oxidized solution of tartrazine and then filled by $1 \mathrm{~L}$ of a new one at the same initial concentration $\left(0.40 \mathrm{~g} \mathrm{~L}^{-1}\right)$ for starting a next cycle.

\section{Results and discussion}

\subsection{Characterization of the materials}

Energy dispersion X-ray (EDX) analysis was performed at two locations on the particle surface, as presented in Figure 3 showing the weight fraction of carbon, oxygen and titanium. A high proportion of Ti has been detected at the surface of the composite material sample (Region I: 25\%, Region II: $18 \%$ ). XRD analysis confirmed the presence of 
(a) \%(weight fraction)

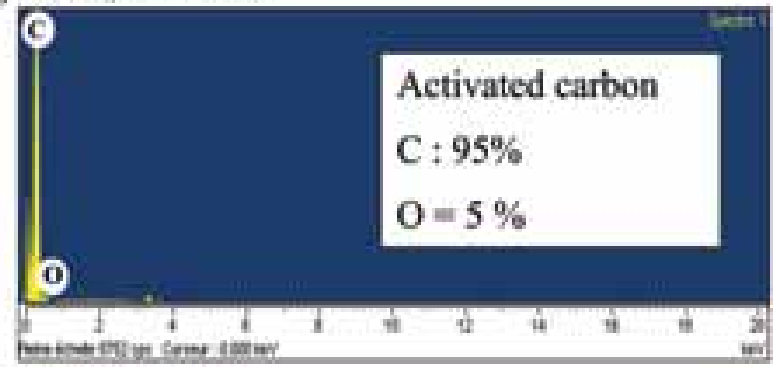

(b)\%o(weizht fraction)

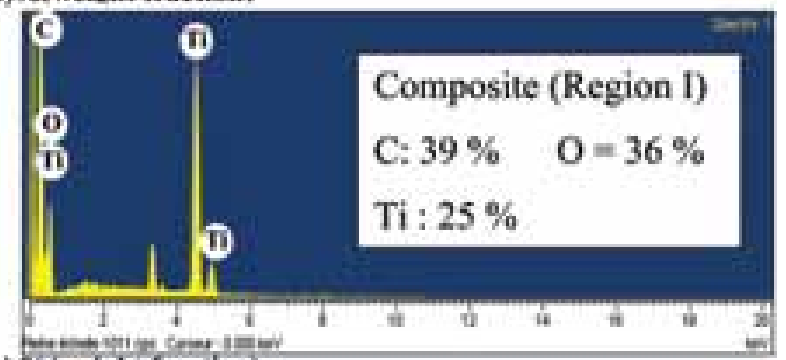

(c) \%(weiche fraction)

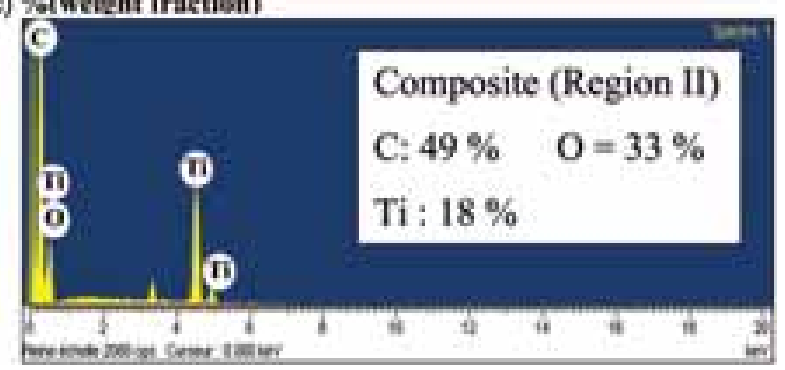

Figure 3. EDX analysis of the materials (\% weight): (a) AC; (b) $\mathrm{TiO}_{2} / \mathrm{AC}$ composite (Region I) and (c) $\mathrm{TiO}_{2} / \mathrm{AC}$ composite (Region II).

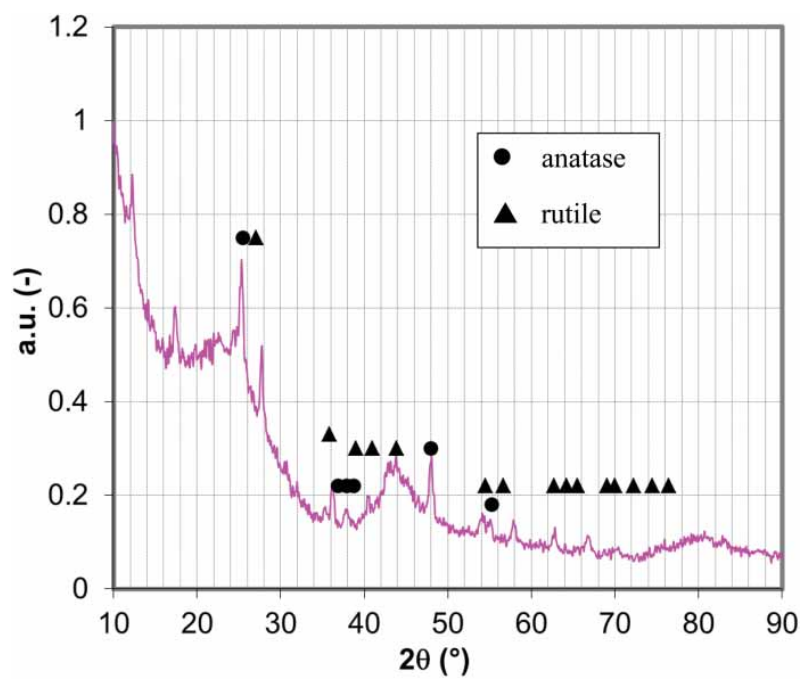

Figure 4. XRD analysis of the $\mathrm{TiO}_{2} / \mathrm{AC}$ composite.

$\mathrm{TiO}_{2}$-anatase and $\mathrm{TiO}_{2}$-rutile (Figure 4). Table 1 indicated $\mathrm{TiO}_{2} / \mathrm{AC}$ composite to have a slightly smaller surface area than $\mathrm{AC}$, the decrease in BET surface being about $12 \%$ suggesting a small fraction of pores located on the external
Table 1. Main characteristics of material.

\begin{tabular}{|c|c|c|}
\hline & \multicolumn{2}{|c|}{ Material } \\
\hline & $\mathrm{AC}$ & $\mathrm{TiO}_{2} / \mathrm{AC}$ \\
\hline BET surface $\left(\mathrm{m}^{2} \mathrm{~g}^{-1}\right)$ & 1100 & 962 \\
\hline Microporous volume $\left(\mathrm{cm}^{3} \mathrm{~g}^{-1}\right)$ & 0.425 & 0.372 \\
\hline Mesoporous volume $\left(\mathrm{cm}^{3} \mathrm{~g}^{-1}\right)$ & 0.046 & 0.041 \\
\hline Pore size $(\AA)$ & 12 & 12 \\
\hline Sauter diameter $\mathrm{d}_{32}(\mu \mathrm{m})$ & 260 & 257 \\
\hline Wt. $\% \mathrm{TiO}_{2}$ & 0 & 7.9 \\
\hline
\end{tabular}

AC surface to be partially blocked by a very thin layer of $\mathrm{TiO}_{2} \cdot[43,44]$ This proved that when $\mathrm{TiO}_{2}$ is deposited into $\mathrm{AC}$ by MOCVD technique, the surface area is not significantly altered although the original $\mathrm{AC}$ was microporous. For $\mathrm{TiO}_{2} / \mathrm{AC}$ composite sample, small decreases in both microporous and mesoporous were observed.

\subsection{Adsorption isotherms}

Langmuir equation was the more convenient one to describe the isotherms represented in Figure 5. The different parameters of the Langmuir model and the correlation coefficients values have been given in Table 2. The good fit with the Langmuir model indicated no formation of adsorbed tartrazine multilayers, in agreement with the microporous properties of the two materials. The values of $q_{\max }$ were of same order of magnitude as the value reported by Gupta et al.,[45] $q_{\max }=0.13 \mathrm{~g} / \mathrm{g}_{\text {adsorbent }}$, for another AC produced from coconut. As expected from BET surface values, the value of $q_{\max }$ of $\mathrm{AC} / \mathrm{TiO}_{2}$ composite material was slightly smaller than that of the mixture of $\mathrm{AC}$ and $\mathrm{TiO}_{2}$.

\subsection{Application of the hybrid process during five cycles}

\subsubsection{Preliminary tests}

The first preliminary test investigated the direct photolysis of tartrazine ( $\mathrm{UV}$ alone - without $\mathrm{TiO}_{2}$ ). Tartrazine degradation under UV irradiation without catalyst was very slow, about $10 \%$ after $2000 \mathrm{~min}$. A second preliminary test investigated was the photocatalytic performance of $\mathrm{TiO}_{2}$ without $\mathrm{AC}$ under $\mathrm{UV}$ irradiation. A volume of $1 \mathrm{~L}$ of aqueous solution of tartrazine $\left(0.32 \mathrm{~g} \mathrm{~L}^{-1}\right)$ and $\mathrm{TiO}_{2}(0.4 \mathrm{~g}$, same as in $\mathrm{TiO}_{2} / \mathrm{AC}$ composite runs) was left in contact for one day in dark condition for preliminary adsorption. After this adsorption step, the system was exposed to UV irradiation for four days. Figure 6 shows the tartrazine concentration profile during this test: $19 \%$ was removed by adsorption onto $\mathrm{TiO}_{2}$, while about $70 \%$ of the remaining fraction in liquid phase was degraded by photocatalysis. The photocatalytic process exhibited very high changes with a first period of very fast degradation during the first hour of UV irradiation where more tartrazine was degraded than during the following $7000 \mathrm{~h}$. This strong final limitation may be related to the high tartrazine $/ \mathrm{TiO}_{2}$ weight ratio $(0.40 \mathrm{~g} / 0.40 \mathrm{~g})$, 


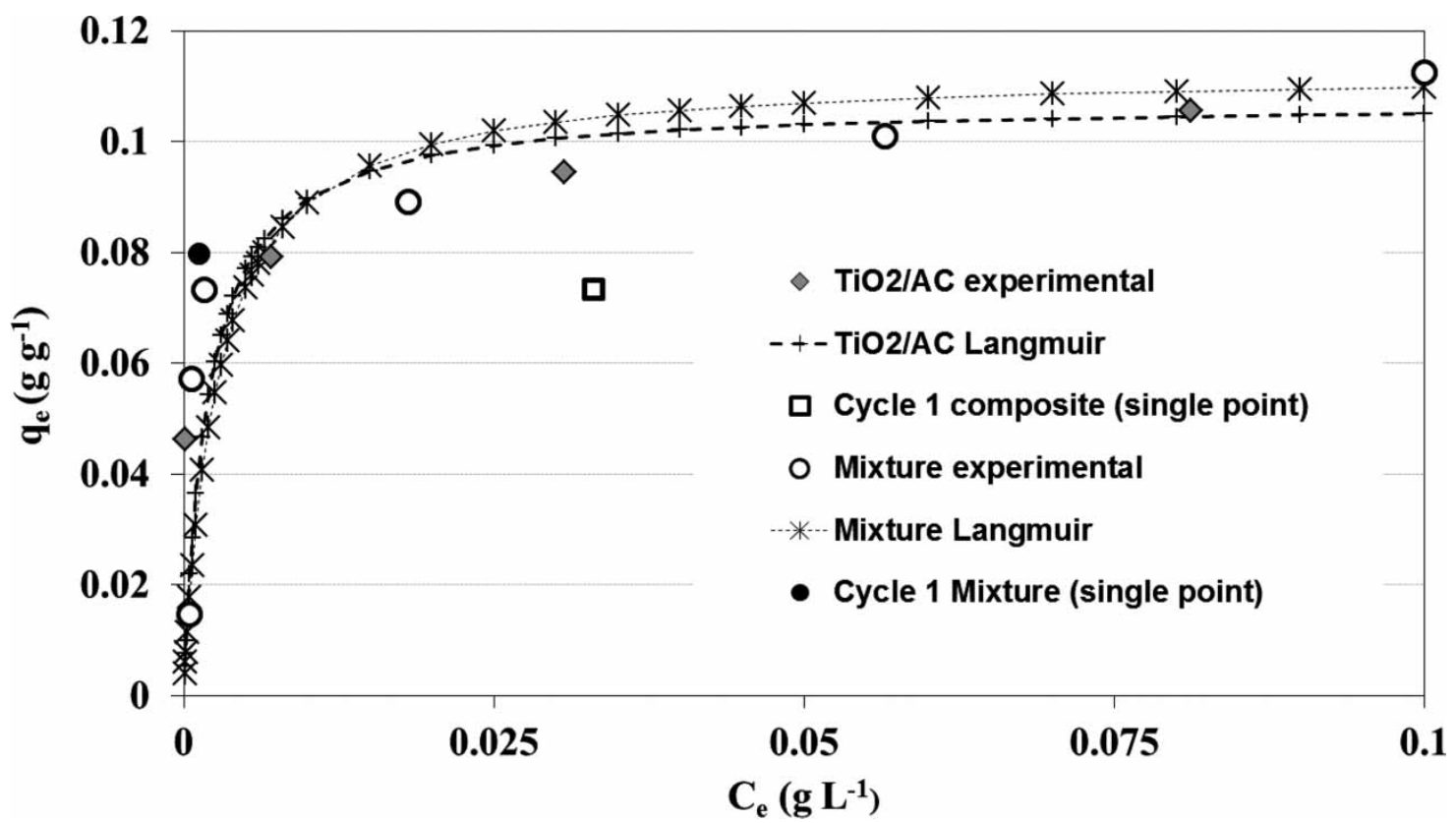

Figure 5. Tartrazine experimental isotherms and modelling Langmuir isotherms obtained with the mixture of $\mathrm{AC}$ and $\mathrm{TiO}_{2}$ and with $\mathrm{TiO}_{2} / \mathrm{AC}$ composite (the experimental points $\square$ and $\bullet$ correspond to the first adsorption steps with both materials).

Table 2. Parameter constants of Langmuir models for tartrazine.

\begin{tabular}{|c|c|c|c|}
\hline \multirow[b]{2}{*}{ Adsorbent } & \multicolumn{3}{|c|}{$\begin{array}{c}\text { Langmuir parameters } \\
q_{e}=q_{\max }\left(C_{e} \cdot K_{L}\right) /\left(1+C e \cdot K_{L}\right)\end{array}$} \\
\hline & $q_{\max }\left(g / g_{\text {adsorbent }}\right)$ & $K_{L}\left(\mathrm{Lg}^{-1}\right)$ & $R^{2}$ \\
\hline $\begin{array}{l}\text { Mixture of } \mathrm{TiO}_{2} \\
\text { and } \mathrm{AC}\end{array}$ & 0.113 & 516 & 0.998 \\
\hline $\begin{array}{l}\mathrm{TiO}_{2} / \mathrm{AC} \\
\quad \text { composite }\end{array}$ & 0.107 & 376 & 0.996 \\
\hline
\end{tabular}

due to the small quantity of catalyst, active photocatalytic sites were blocked by a high amount of adsorbed molecules which absorbed a part of the UV light emitted by the lamp (340-400 nm). Consecutively, the amount of photon reaching the catalyst surface decreased, reducing drastically the degradation rate.[46,47]

\subsubsection{Adsorption steps}

Two series of four cycles of adsorption-photocatalytic regeneration have been carried out with the two solid materials, powder mixture and composite with the same weights of $\mathrm{AC}$ and $\mathrm{TiO}_{2}$. For the first cycle, Figure 7(a) and 7(c) showed first adsorption to be faster with the powder mixture than with the composite. At the end of the first adsorption run nearly $100 \%$ of the pollutant left the liquid phase, being adsorbed by the solid mixture, while only $90 \%$ had been adsorbed on the $\mathrm{TiO}_{2} / \mathrm{AC}$ composite. In the last case, the equilibrium was not achieved due to slower kinetics, as isotherms were seen as very similar (see Figure 5, where the points 'Cycle 1 composite' and 'cycle 1 Mixture' have been added for comparison with isotherms). Two possible explanations of the slower adsorption with the composite would be: (i) an additional layer of $\mathrm{TiO}_{2}$ should be crossed (ii) $\mathrm{TiO}_{2}$ deposit reduced not only the porous volume but more significantly surface diffusion in the pores. For the next other cycles, adsorption efficiency was significantly reduced in both systems, indicating incomplete photocatalytic regeneration. With the $\mathrm{AC}$ and $\mathrm{TiO}_{2}$ mixture, the loss of adsorption capacity was clearly more important suggesting lower photocatalytic regeneration. Table 3 and Figure 8 confirmed the better adsorption efficiency with $\mathrm{TiO}_{2} / \mathrm{AC}$ composite after the first cycle. The total quantity of the adsorbed tartrazine during the four cycles was $10 \%$ higher on $\mathrm{TiO}_{2} / \mathrm{AC}$ composite than on the solid mixture. For both materials, the cumulated amounts (four cycles) were nearly twice the maximum adsorption capacities, $q_{\max }$ of the Langmuir model (Table 2). Higher re-adsorption despite lower initial adsorption kinetics suggested an improved photocatalytic regeneration of $\mathrm{AC}$ on $\mathrm{TiO}_{2} / \mathrm{AC}$ composite as compared with the solid mixture.

\subsubsection{Photocatalysis steps}

As shown in Figure 7(b) and 7(d), Tartrazine was totally degraded with the two materials during the first photooxidation cycle. The reaction rate was much higher with the composite: $96 \%$ conversion within $3 \mathrm{~h}$ vs. $80 \%$ with the separate materials. As for the adsorption step, the photo-oxidation step was progressively reduced during the following cycles towards a quasi-steady behaviour with very similar third and fourth cycles. Here again, $\mathrm{TiO}_{2} / \mathrm{AC}$ 


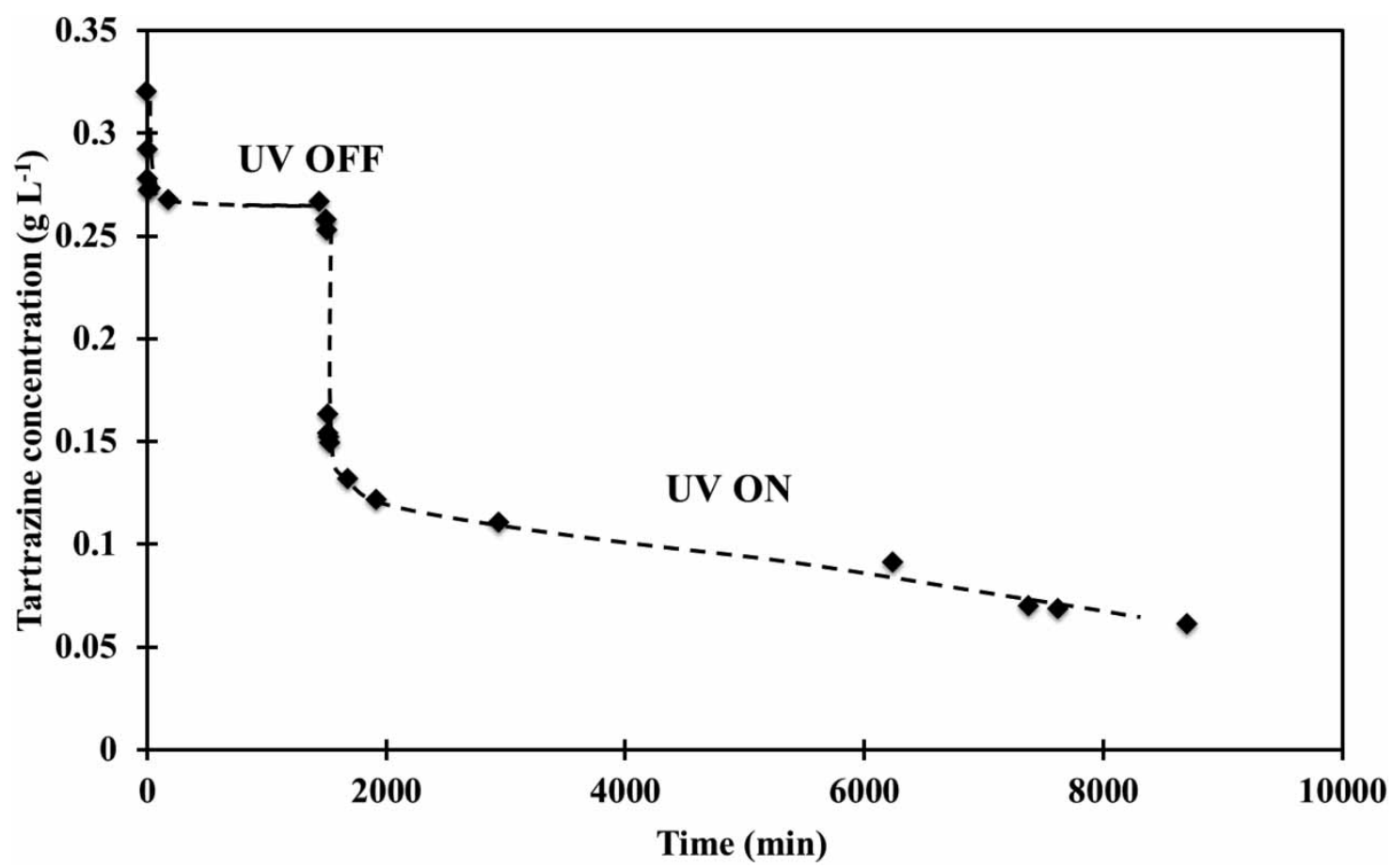

Figure 6. Kinetic of tartrazine adsorption (UV OFF) and photocatalytic oxidation with $\mathrm{TiO}_{2}$ alone under $\mathrm{UV}$ irradiation at $25^{\circ} \mathrm{C}$ without $\mathrm{AC}\left(1 \mathrm{~L}, C_{0}=0.32 \mathrm{~g} \mathrm{~L}^{-1}, \mathrm{~m}_{\mathrm{TiO}_{2}}=0.4 \mathrm{~g}\right.$ and light intensity $\left.47.5 \mathrm{~W} \mathrm{~m}^{-2}\right)$.
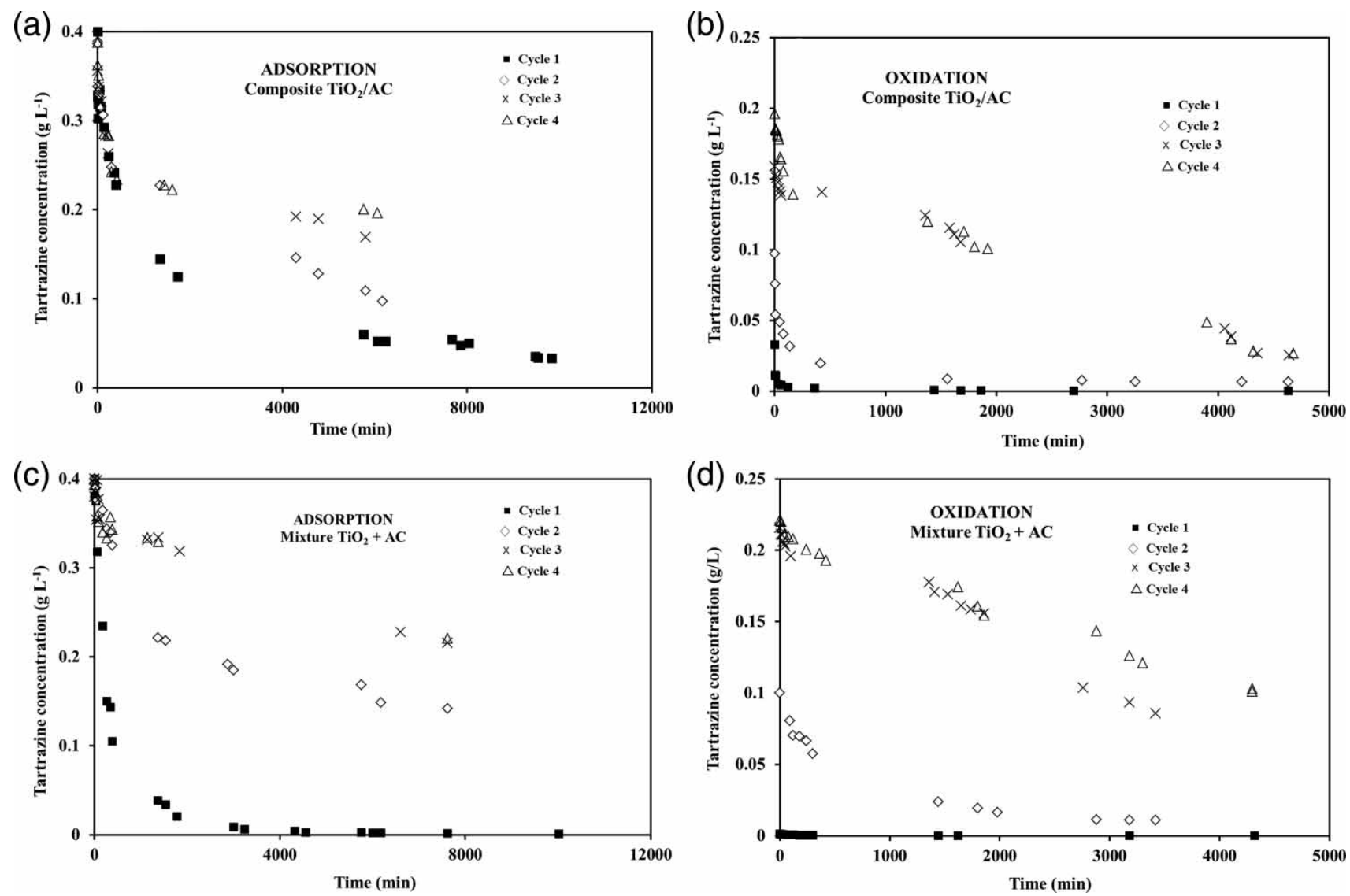

Figure 7. Tartrazine concentration-time measured for the four cycles using $\mathrm{TiO}_{2} / \mathrm{AC}$ composite and the mixture of $\mathrm{TiO}_{2}$ and $\mathrm{AC}$ during adsorption step and photocatalytic oxidation step: (a) adsorption composite material; (b) oxidation composite material; (c) adsorption mixture and $(\mathrm{d})$ oxidation mixture $\left(T=25^{\circ} \mathrm{C}, 1 \mathrm{~L}, C_{0}=0.4 \mathrm{~mol} \mathrm{~L}-1\right.$, mixture: $\mathrm{m}_{\mathrm{TiO}_{2}}=0.4 \mathrm{~g}$ and $\left.m_{\mathrm{AC}}=4.6 \mathrm{~g}, \mathrm{~m}_{\mathrm{TiO}_{2} / \mathrm{AC}}=5 \mathrm{~g}\right)$. 
Table 3. Comparison of the tartrazine adsorbed quantity during four cycles of adsorption for $\mathrm{TiO}_{2} / \mathrm{AC}$ composite and the mixture of $\mathrm{AC}$ and $\mathrm{TiO}_{2}$ powder.

\begin{tabular}{lccccc}
\hline & \multicolumn{5}{c}{ Amount of tartrazine adsorbed $\left(g / g_{\text {adsorbent }}\right)$} \\
\cline { 2 - 6 } & & & & & Total quantities \\
Adsorbent & $q_{\mathrm{AD} 1}$ & $q_{\mathrm{AD} 2}$ & $q_{\mathrm{AD} 3}$ & $q_{\mathrm{AD} 4}$ & $q_{\text {total }}=q_{\mathrm{AD} 1}+q_{\mathrm{AD} 2}+q_{\mathrm{AD} 3}+q_{\mathrm{AD} 4}$ \\
\hline Mixture of $\mathrm{TiO}_{2}$ and AC & 0.076 & 0.049 & 0.035 & 0.034 & 0.194 \\
$\mathrm{TiO}_{2} / \mathrm{AC}$ composite & 0.074 & 0.058 & 0.047 & 0.038 & 0.217 \\
\hline
\end{tabular}

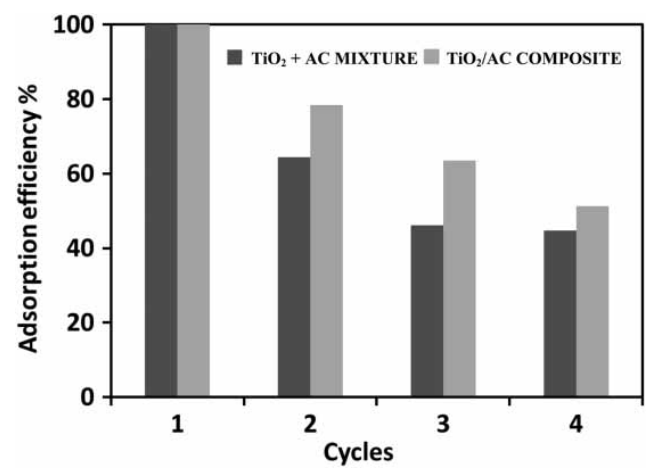

Figure 8. Comparison of adsorption efficiency evolution during four cycles $\left(q_{\mathrm{ADi}} / q_{\mathrm{AD} 1}^{*} 100\right)$ for $\mathrm{TiO}_{2} / \mathrm{AC}$ composite and the mixture of $\mathrm{AC}$ and $\mathrm{TiO}_{2}$ powder.

performed much better, leading to more than $80 \%$ degradation in liquid phase while a continuous decrease in degradation rate was observed with the solid mixture, down to less than $50 \%$ at the fourth cycle.

The photocatalyst was then much more efficient when deposited on the $\mathrm{AC}$ as already shown by Wang et al. [48] and Xue et al.[49] The location of the adsorption and photocatalysis sites close to each other improved the conditions of oxidation, by lowering the diffusion step in between. A comparison of the reduction in TOC values for each cycle for both photocatalysis implementations was presented in Figure 9. Surprisingly TOC reduction was much higher than tartrazine degradation as observed in Figure 7(b) and 7(d). Indeed, this was due to accumulation of by-products which are predominant: tartrazine contribution to TOC is only $25 \%$ in the final cycle. The results also showed that the TOC removal using $\mathrm{TiO}_{2} / \mathrm{AC}$ composite was always higher than when using separate $\mathrm{TiO}_{2}$ and $\mathrm{AC}$ powders in the suspension mixture. The best mineralization with $\mathrm{TiO}_{2} / \mathrm{AC}$ composite material was probably due to the vicinity of photocatalyst and $\mathrm{AC}$ adsorption sites. During the degradation of tartrazine, a part of the intermediates was adsorbed and was not transferred in liquid phase. Then, they were oxidized directly; there was no longer a possible limitation due to the step of transfer of the reactants from the fluid phase to the surface of the catalyst. The vicinity of photocatalytic and adsorption sites significantly accelerated the transfer step between the two sites and the overall oxidative regeneration process.

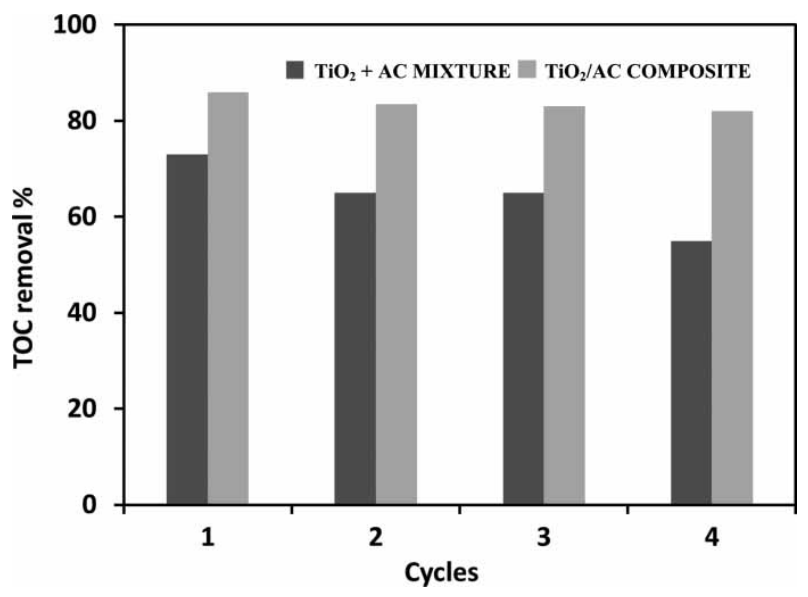

Figure 9. Comparison of the final TOC removal with the mixture of $\mathrm{AC}$ and $\mathrm{TiO}_{2}$ powder and with the $\mathrm{TiO}_{2} / \mathrm{AC}$ composite for the four photocatalytic oxidation steps.

\section{Conclusion}

Nanocrystalline $\mathrm{TiO}_{2}$ deposited on AC by MOCVD preserved most of AC adsorption capacity. Such composite of $\mathrm{TiO}_{2} / \mathrm{AC}$ materials exhibited photocatalytic activity for the degradation of tartrazine. By cyclic use of the catalyst deposited on $\mathrm{AC}$ up to $80 \%$ of tartrazine degradation was observed in liquid phase until the fourth cycle while only $50 \%$ with powder $\mathrm{TiO}_{2}$ mixed with granular $\mathrm{AC}$. The best performances with $\mathrm{TiO}_{2}$ deposited on $\mathrm{AC}$ could be explained by a fast transfer of the organic compounds from adsorption sites to photocatalytic sites. The concentration of desorbing molecules near the photocatalytic sites should be much higher than when a diffusion through liquid phase is required from $\mathrm{AC}$ to $\mathrm{TiO}_{2}$ particles.

\section{Acknowledgements}

The authors wish to acknowledge the financial support of the MidiPyrénées French region.

\section{References}

[1] Bansal P, Singh D, Sud D. Photocatalytic degradation of azo dye in aqueous $\mathrm{TiO}_{2}$ suspension: reaction pathway and identification of intermediates products by LC/MS. Sep Purif Technol. 2010;72:357-365.

[2] Neppolian B, Choi HC, Sakthivel S, Arabindoo B, Murugesan V. Solar/UV induced photocatalytic degradation of three commercial textile dyes. J Hazard Mater. 2002;89:303-317. 
[3] Konstantinou IK, Albanis TA. $\mathrm{TiO}_{2}$-assisted photocatalytic degradation of azo dyes in aqueous solution: kinetic and mechanistic investigations. A review. Appl Catal B: Environ. 2004;49:1-14.

[4] Guetta N, Amar HA. Photocatalytic oxidation of methyl orange in presence of titanium dioxide in aqueous suspension. Part II: kinetics study. Desalination. 2005;185: 439-448.

[5] Mahmoodi NM, Arami M, Limaee NY, Tabrizi NS. Kinetics of heterogeneous photocatalytic degradation of reactive dyes in an immobilized $\mathrm{TiO}_{2}$ photocatalytic reactor. J Colloid Inter Sci. 2006;295:159-164.

[6] Barka N, Qourzal S, Assabbane A, Nounahb A, Ait-Ichou Y. Factors influencing the photocatalytic degradation of Rhodamine $\mathrm{B}$ by $\mathrm{TiO}_{2}$-coated non-woven pape. J Photochem Photobiol A: Chem. 2008;195:346-351.

[7] Sopyan I, Watanabe M, Murasawa S, Hashimoto K, Fujishima A. An efficient $\mathrm{TiO}_{2}$ thin-film photocatalyst: photocatalytic properties in gas-phase acetaldehyde degradation. J Photochem Photobiol A: Chem. 1996;98:79-86.

[8] Arana J, Melian JAH, Rodriguez JMD, Diaz OG, Viera A, Pena JP, Sosa PMM, Jimenez VE. $\mathrm{TiO}_{2}$-photocatalysis as a tertiary treatment of naturally treated wastewater. Catal Today. 2002;76:279-289.

[9] Chun H, Yizong W, Hongxiao T. Preparation and characterization of surface bond-conjugated $\mathrm{TiO}_{2} / \mathrm{SiO}_{2}$ and photocatalysis for azo dyes. Appl Catal B: Environ. 2001;30: 277-285.

[10] Hosseini SN, Borghei SM, Vossoughi M, Taghavinia N. Immobilization of $\mathrm{TiO}_{2}$ on perlite granules for photocatalytic degradation of phenol. Appl Catal B: Environ. 2007;74:53-62.

[11] Nakata K, Fujishima A. $\mathrm{TiO}_{2}$ photocatalysis: design and applications. J Photochem Photobiol C: Photochem Rev. 2012;13:169-189.

[12] Song P, Irie Y, Shigesato Y. Crystallinity and photocatalytic activity of $\mathrm{TiO}_{2}$ films deposited by reactive sputtering with radio frequency substrate bias. Thin Solid Films. 2006;496:121-125.

[13] Zhang X, Zhou M, Lei L. Preparation of photocatalytic $\mathrm{TiO}_{2}$ coatings of nanosized particles on activated carbon by APMOCVD. Carbon. 2005;43:1700-1708.

[14] Chen Y, Dionysiou D. $\mathrm{TiO}_{2}$ photocatalytic films on stainless steel: the role of degussa P 25 in modified sol-gel methods. Appl Catal B: Environ. 2006;63:255-264.

[15] Zhang X, Zhou M, Lei L. $\mathrm{TiO}_{2}$ photocatalyst deposition by MOCVD on activated carbon. Carbon. 2006;44:325-333.

[16] Jung S, Kim S, Imaishi N. Effect of $\mathrm{TiO}_{2}$ thin film thickness and specific surface area by low-pressure metal-organic chemical vapour deposition on photocatalytic activities. Appl Catal B: Environ. 2005;55:253-257.

[17] Zhang X, Zhou M, Lei L. Enhancing the concentration of $\mathrm{TiO}_{2}$ photocatalyst on the external surface of activated carbon by MOCVD. Mater Res Bull. 2005;40:1899-1904.

[18] Zhang X, Zhou M, Lei L. Preparation of anatase $\mathrm{TiO}_{2}$ supported on alumina by different metal organic chemical vapor deposition methods. Appl Catal A Gen. 2005;282:285-293.

[19] Pozzo RL, Baltan MA, Cassano AE. Supported titanium oxide as photocatalyst in water decontamination: state of the art. Catal Today. 1997;39:219-231.

[20] Tanguay JF, Suib SL, Coughlin RW. Dichloromethane photodegradation using titanium catalysts. J Catal. 1989;117: 335-347.

[21] Tryba B, Morawski AW, Inagaki M. Application of $\mathrm{TiO}_{2}-$ mounted activated carbon to the removal of phenol from water. Appl Catal B: Environ. 2003;41:427-433.
[22] Matos J, Laine J, Hermann JM. Effect of the type of activated carbons on the photocatalytic degradation of aqueous organic pollutants by UV-irradiated titania. J Catal. 2001;200:10-20.

[23] Matos J, Chovelon JM, Cordero T, Ferronato C. Influence of surface properties of acivated carbon on photocatalytic activity of $\mathrm{TiO}_{2}$ in 4-chlorophenol degradation. Open Envrion Eng J. 2009;2:21-29.

[24] Tsumura $\mathrm{T}$, Kojitani $\mathrm{N}$, Umemura $\mathrm{H}$, Toyoda $\mathrm{M}$, Inagaki M. Composites between photoactive anatase-type $\mathrm{TiO}_{2}$ and adsorptive carbon. Appl Surf Sci. 2002;196:429-36.

[25] Herrmann JM, Matos J, Disdier J, Guillard C, Laine J, Malato S, Blanco J. Solar photocatalytic degradation of 4- chlorophenol using synergistic effect between titania and activated carbon in aqueous suspension. Catal Today. 1999;54:255-265.

[26] Yao SH, Jia YF, Zhao SL. Photocatalytic oxidation and removal of arsenite by titanium dioxide supported on granular activated carbon. Environ Technol. 2012;33:983-988.

[27] Lee D, Kim S, Cho I, Kim S. Photocatalytic oxidation of microcystin-LR in a fluidized bed reactor having $\mathrm{TiO}_{2}-$ coated activated carbon. Sep Purif Technol. 2004;34:59-66.

[28] Toyoda M, Nanbu Y, Kito T, Hiranob M, Inagaki M. Preparation and performance of anatase-loaded porous carbons for water purification. Desalination. 2003;159:273-282.

[29] Khan AY, Mazyck DW. A new route for preparation of $\mathrm{TiO}_{2}$-mounted activated carbon. Appl Catal B: Environ. 2003;46:203-208.

[30] Sun LM, Meunier F. Adsorption. Aspects théoriques. Techn Ing. 2003;J2730:1-16.

[31] El-Sheikh AH, Newman AP, Al-Daffaee H, Phull S, Cresswell N, York S. Deposition of anatase on the surface of activated carbon. Surf Coat Technol. 2002;187:284-292.

[32] Mahadwad OK, Parikh PA, Jasra RV, Patil C. Photocatalytic degradation of reactive black-5 dye using $\mathrm{TiO}_{2}$-impregnated activated carbon. Environ Technol. 2012;33:307-312.

[33] Mills A, Elliott N, Parkin IP, O Neill SA, Clark RJ Novel $\mathrm{TiO}_{2} \mathrm{CVD}$ films for semiconductor photocatalysis. J Photochem Photobiol A. 2002;15:171-179.

[34] Ding Z, Hu XJ, Yue PL, Lu GQ, Greenfield PF. Novel silica gel supported $\mathrm{TiO}_{2}$ photocatalyst synthesized by CVD method. Langmuir. 2000;16:6216-6222.

[35] Aksoylu AE, Faria JL, Pereira MFR, Figueiredo JL, Serp P, Hierso JC. Highly dispersed activated carbon supported platinum catalysts prepared by OMCVD: a comparison with wet impregnated catalysts. Appl Catal A. 2003;243:357-365.

[36] Polaert I, Wilhelm AM, Delmas H. Phenol wastewater treatment by a two-step adsorption-oxidation process on activated carbon. Chem Eng Sci. 2002;57:1585-1590.

[37] Julcour-Lebigue C, Krou NG, Andriantsiferana C, Delmas $\mathrm{H}$, Wilhelm AM. Assessment and modeling of a sequential process for water treatment-adsorption and batch CWAO regeneration of activated carbon. Ind Eng Chem Res. 2012;51:8867-8874.

[38] Cadoret L, Reuge N, Pannala S, Syamlal M, Rossignol C, Dexpert-Ghys J, Coufort C, Caussat B. Silicon chemical vapor deposition on macro and submicron powders in a fluidized bed. Powd Technol. 2009;190:185-191.

[39] Reuge N, Dexpert-Ghys J, Caussat B. Fluidized-bed MOCVD of $\mathrm{Bi}_{2} \mathrm{O}_{3}$ thin films from bismuth triphenyl under atmospheric pressure. Chem Vapor Depos. 2010;16: $123-126$.

[40] Brunauer S, Emmett PH, Teller E. Adsorption of gases in multimolecular layers. J Am Chem Soc. 1938;60:309-319.

[41] Horvath G, Kawazoe KJ. Method for the calculation of effective pore size distribution in molecular sieve carbon. Chem Eng Jpn. 1983;16:470-475. 
[42] Barrett EP, Joyner LG, Halenda PP. The determination of pore volume and area distributions in porous substances. J Am Chem Soc. 1951;73:373-380.

[43] Zhang X, Lei L. Effect of preparation methods on the structure and catalytic performance of $\mathrm{TiO}_{2} / \mathrm{AC}$ photocatalysts. J Hazard Mater. 2008;153:827-833.

[44] Zhu B, Zou L. Removal of color compounds from recycled water using combined activated carbon adsorption and AOP decomposition. J Adv Oxid Technol. 2009;12: 47-54.

[45] Gupta VK, Jain R, Shrivastava M, Nayak A. Equilibrium and thermodynamic studies on the adsorption of dye tartrazine onto Waste "coconuts husks" carbon and activated carbon. J Chem Eng Data. 2010;55:50835090 .
[46] Qamar M, Saquib M, Muneer M. Semiconductor-mediated photocatalytic degradation of an azo dye, chrysoidine $\mathrm{Y}$ in aqueous suspensions. Desalination. 2005;171:185-193.

[47] Wang JP, Chen YZ, Feng HM, Zhang SJ, Yu HQ. Removal of 2,4-dichlorophenol from aqueous solution by static-airactivated carbon fibers. J Colloid Interface Sci. 2007;313:80 85.

[48] Wang X, Hu Z, Chen Y, Zhao G, Liu Y, Wen Z. A novel approach towards high performance composite photocatalyst of $\mathrm{TiO}_{2}$ deposited on activated carbon. Appl Surf Sci. 2009;255:3953-3958.

[49] Xue G, Liu H, Chen Q, Hills C, Tyrer M, Innocent F. Synergy between surface adsorption and photocatalysis during degradation of humic acid on $\mathrm{TiO}_{2} /$ activated carbon composites. J Hazard Mater. 2011;186:765-772. 